Agropedology 2016, 26 (01), 57-68

\title{
Land Use Issues in Selected Disadvantaged Districts of Eastern India
}

\author{
N. G. Patil*, A. Chaturvedi and S. K. Singh \\ ICAR - National Bureau of Soil Survey and Land Use Planning, Nagpur - 440 033, India
}

\begin{abstract}
Status of current land use and development vis-a-vis available resources in 58 disadvantaged districts out of 150 in three different agro-ecological regions (AER) namely 11, 12 and 13 of eastern India were analyzed. Expectedly fragmentation of agriculture land holdings and declining per capita land availability emerged as major constraints. The analysis also indicated that development of water resource(s) is the most critical factor in AER 11 and 12 where protectionist forest laws appeared to have detrimental effect on irrigation development as evident from empirical negative relationship between irrigation development and forest area. It is argued that developmental plans and land use strategies in AER-11,12 must be aimed at irrigation development and formulating sustainable non-timber forest produce (NTFP) utilization. Forest lands near villages need to be used for short, middle and long term plans to provide NTFP as a means of livelihood. Based on experimental results it is argued that there exists potential to grow legume crops using residual soil moisture after rainfed rice. AER 13 has very insignificant forest area and well developed irrigation but faces heavy population pressure. Cultivated area in this AER exceeds $74 \%$ and hence improving water use efficiency appears to be the emergent option for enhanced productivity. Other land uses such as industrial development are urgently required in AER 13 to relieve population pressure. We argue for revision of land use policies especially tenancy and share cropping and advocate inventory of natural resources with an agro-ecological approach.
\end{abstract}

Keywords: Land use, poverty, natural resources, agro-ecological region, forest, irrigation development

\section{Introduction}

The pace of farm employment growth in India has lagged behind the population growth. Consequently despite having seventh largest landmass in the world, the per capita land availability has rapidly declined, from 0.46 ha in 1951 to 0.11 ha by 2001 (Chaturvedi et al.2011). The consequences are disastrous for quality and sustainability of land use.The direct impact is deterioration of land quality that is manifested in water availability and shrinkage of vegetation. Small land holdings and inadequate water resources development have combined to create plethora of problems that cannot be solved easily. Consequently there are large areas in the country debilitated by poverty despite possessing adequate natural resources.

The Planning commission, Govt. of India has identified 150 most disadvantaged districts of the country on the basis of prevalence of poverty indicated by population of oppressed castes/tribes (listed in the schedule by the Government), agricultural productivity per worker and

*Corresponding Author Email: nitpat03@yahoo.co.uk agricultural wage rate. These districts are covered under the National Food for Work programme. Most of them happen to be tribal districts. It is felt that there is a need for substantial additional investment in these districts to convert their surplus labour into required capital formation solving livelihood issues.

The Indian Council of Agriculture Research (ICAR) has selected these districts under component 3 of the National Agricultural Innovation Project (NAIP), which accords high priority to improve livelihood security of rural people living in the selected disadvantaged regions through technology-led innovation systems, encompassing the wider process of social and economic change covering all stakeholders. Conceptualised in consortium mode, the programme envisages building partnerships, pool competence and resources from conventional and unconventional sources and building social capital for better ownership and sustainable model of rural development. Out of these 150 most disadvantages districts, 58 fell in Eastern India. The Eastern Region comprising of Eastern UP $(85,844$ sq km), Bihar including Jharkhand(1,73,877 sq km), West 
Bengal (88,752 sq km), Assam (78,438 sq km), Orissa $(1,55,707 \mathrm{sq} \mathrm{km})$, and Chhattisgarh $(1,44,422 \mathrm{sq} \mathrm{km})$ occupies about $28 \%$ of the country's geographical area and is inhabited by about $35 \%$ of the country's population. The region has 1.24 times higher population density than the national average (Planning Commission 2001). Per capita availability of total land/net cultivated land in the Eastern Region is lowest in the country. In view of the highest percentage of net sown area to geographical area, there is hardly any scope for enlarging the area under cultivation in this region. Most of the farm holdings are marginal to small, and highly fragmented, hampering the adoption of high-tech agriculture. Water resources in the region are not utilized to optimum extent and hence there lies ample scope for intensification of agriculture. These problems become further severe in disadvantaged districts.

What are the ideal land use strategies for these disadvantaged districts to ensure higher capital formation and improve livelihood of the people? One has to understand the natural resource base of these districts and the socioeconomic milieu of the region to decide broad strategies for such areas. In the present paper, an attempt has been made to evaluate the natural resource base and their utilization in the disadvantaged districts of eastern India to identify the major issues which need to be addressed for improving the livelihood on a sustainable basis. Emphasis is also placed on steps to improve the use efficiency of the resources. The authors' experience of working in one of the disadvantaged districts in Maharashtra (Aurangabad, Dhule and Gondia) is illustrated to demonstrate how simple steps in improving rainwater use-efficiency can make difference in changing the land use of the area for livelihood security.

\section{Material and Methods}

The 150 disadvantaged districts of India are shown in Fig. 1. For preparation of inventory of natural resources of these 150 disadvantaged districts, many sources were accessed. The collected information includes land use-total geographical area, cultivated area, forest cover, degraded land, waste land, mean annual rainfall, groundwater development, irrigated area, waterlogged area, human population, and productivity of major crops. The data were analysed for population density, per capita land availability, percent forest cover (to the total geographical area), and other parameters such as percent net cultivated area, productivity per unit of land, etc. All the calculations were performed in MS-Excel using standard statistical procedures. The data sources are-national websites of National Informatics Centre for each district, those of agriculture department of each Indian state involved, website of Central Ground Water Board (CGWB), Ministry of Environment and Forest (Govt of India), State Forest Department, Rice Directorate (Govt. of India), Department of Agriculture (Govt of India). There were disparities in data. For instance, CGWB report and state agriculture department statistics about forest cover and/or irrigated area often differed. The latest available data were preferred whenever timeline was available. Where such information was unavailable, the data were crosschecked with other reports like research articles, status reports compiled by other departments, planning department of state/district/block. Concerned officials, researchers, Non Government Organizations etc. were contacted for verification of the data whenever doubts were raised about the data.

The natural resource base of these districts can best be understood by appreciating the agro-ecological settings where they exist. The base for studying the 150 districts needs to be a set of groupings of homogenous characteristics. Since our emphasis is on natural resources it was decided to use the Agro Ecological Region (AER) approach for the same. Agro-ecological zoning (AEZ) refers to the division of an area of land into smaller units within a geographical continuum, which have similar characteristics related to land suitability, potential production and environmental impact. An agro-ecological zone or region is a product of agroecological zoning and is a land resources mapping unit, defined in terms of climate, landform and soils, and/or land cover with a specific range of potentials and constraints with respect to land use (Gajbhiye and Mandal 2008). 


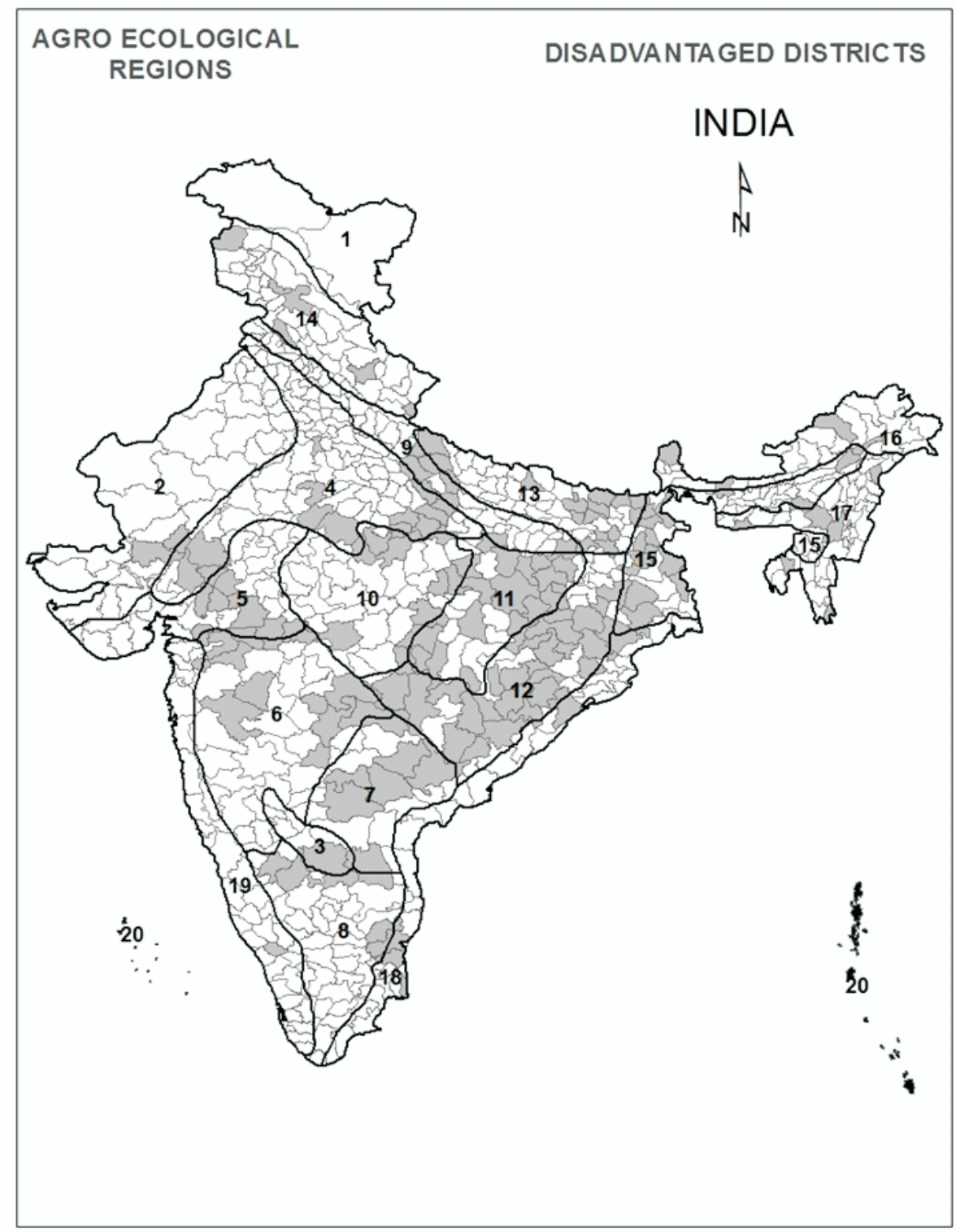

Fig. 1 Agro-ecological regions and 150 disadvantaged districts of India

The distribution of disadvantaged districts of India showing that majority of the districts exist in clusters (Fig. 1). 
Only 14 districts are located in isolation, out of which 8 are in the North and North East hilly regions, where undulating to ropy terrain and accessibility may be an issue. The highest (25) number of disadvantaged districts are located in AER 12 (Eastern Plateau, Chhattisgarh, hot suhmid ecoregion, with red and yellow soils, crop growing period of (GP) 150-180 days); followed by 17 in AER11 (Eastern Chota Nagpur Plateau and Eastern Ghats, hot subhumid ecoregion, with red and lateritic soils and growing period of 150-180-210 days); and 16 in AER13 (Eastern Plain, hot subhumid, moist ecoregion, with alluvium-derived soils and growing period of 180-210 days). These three AERs together constitute 58 disadvantaged districts consisting $52 \%$ of the total districts, in the region. The scope of this article is limited to 58 districts of AER11, 12 and 13 (listed in Table 1) of the eastern region.

Table 1. List of 58 Disadvantaged districts in AER 11, 12 and13 of India

\begin{tabular}{|l|l|}
\hline Federal State & Disadvantaged Districts \\
\hline Bihar & $\begin{array}{l}\text { Araria, Vaishali, Madhubani, Muzaffarpur, Nawadah, Samastipur, Sheohar, Jamui, } \\
\text { Lakhisarai, Munger, Purnea, Supaul, Darbhanga }\end{array}$ \\
\hline Chhattisgarh & $\begin{array}{l}\text { Koria, Sarguja, Jaspur, Dhamtari, Raigarh, Bilaspur, Rajnandgaon, Bastar, } \\
\text { Dantewada, Kanker }\end{array}$ \\
\hline Jharkhand & $\begin{array}{l}\text { Gumla, Chatra, Garhwa, Palamau, Latehar, Lohardaga, Saraikela, Singhbhum } \\
\text { West, Simdega }\end{array}$ \\
\hline Madhya Pradesh & Balaghat \\
\hline Maharashtra & Gondia, Gadchiroli, Chandrapur \\
\hline Orissa & $\begin{array}{l}\text { Koraput, Malkangiri, Nabrangapur, Rayagada, Sundargarh, Keonijhar, Phulbani, } \\
\text { Boudh, Nuapada, Kalahandi, Sambalpur, Deogarh, Jharsuguda, Sonepur, Bolangir, } \\
\text { Dhenkenal }\end{array}$ \\
\hline Uttar Pradesh & Sonabhadra, Mirzapur, Sitapur, Lakhmipur Kheri, Kushinagar \\
\hline West Bengal & Purulia \\
\hline
\end{tabular}

\section{Results and Discussion}

Current land use indicates that AER 11 and AER 12 are richer (Table 2) in terms of forest resources while AER 13 is better off in terms of agriculture resources, i.e., soil quality and water resources (irrigation). In the context of the Eastern Plateau and Plains, it is observed that AER 11 and 12 is contiguous unit classified as Eastern Plateau (Chhattisgarh) and Eastern Plateau (Chhota Nagpur) respectively. AER 13 is classified as Eastern Plains. For comparison purpose AER 11 and 12 are clubbed together due to common characteristics such as almost equal forest cover $(37 \%)$ shallow soils, high rainfall $(>1000 \mathrm{~mm})$ etc. AER 13 is typified by negligible forest cover (8\%), rich alluvial soils and $1200 \mathrm{~mm}$ rainfall. AER 11, 12 and AER 13 differ in terms of land use, utilization of water resources, socio-economics as evident from Table 2. For instance only 5 districts (namely Balaghat, Singbhum, Palamu, Dhamtari and Gondia) from AER 11, 12 have developed significant irrigation (Fig. 2) facilities ( $>35 \%$ irrigated area). Since India has around $35 \%$ of its crop area irrigated, we consider
$35 \%$ as a threshold value. Rest of the 36 districts are yet to utilize their irrigation potential. These districts vary in irrigation development from 1 to $34 \%$. Ironically, all the districts receive more than $1200 \mathrm{~mm}$ rainfall and are located in assured rainfall zone. Analysis in this article focuses on AER 11, 12 (treated as a single entity in the context of this article) and 13 for comparison and evaluation.

\section{Land Use and Poverty}

The existing land use in disadvantaged districts of AER 11, 12 and 13 is listed in Table 2. It is apparent that AER 13 is inhabited by more than double human population as compared to AER 11 despite relatively less (47\% less) TGA. The land use statistics also exemplify enormous pressure on land resources in AER 13 as more than $74 \%$ of the land is already under cultivation leaving only about $25 \%$ of land for other uses such as habitation, industry, roads, recreation, infrastructure etc. The major challenge is to sustain livelihood of over 30 million people with $2.97 \mathrm{M}$ ha land. In agriculture development there are two clear facets-first to 
increase agricultural production without any horizontal expansion and second to minimise decline in net sown area especially in fertile plains. The land use policy must consider these limitations for sustaining the agricultural production. Various studies have brought out that wherever the soils are good, there is larger number of holdings of smaller size (Chaturvedi et al. 2011). Small holding lands are often economically non-viable to support the family, compelling owners to concentrate more on wage employment. Consequently, tiny holdings are often neglected (Rathore and Pal 2000). There are no authentic reports but estimates show that less than $2 \%$ of the landlords in Uttar Pradesh owned nearly $58 \%$ of the land. The situation is expected to be relatively worse in disadvantaged districts of the state especially AER 13. Paradoxically, fragmentation of land is also a major issue affecting agricultural productivity in this AER. The proportion of land area under agricultural use in India $(46 \%)$ is much larger compared to world (11\%). It is more than $74 \%$ in AER 13. Land fragmentation is positively and significantly associated with inefficiency whereas land ownership and crop diversity is negatively and significantly associated with inefficiency (Manjunatha et al. 2013). Per capita arable land availability in India is currently estimated to be 0.13 ha (Chandran et al. 2014). Likelihood of suboptimal usage of inputs and low productivity is always greater in such scenario. Constraints imposed by small land holdings are many including inability to practice mechanized agriculture, loss of space in marking field boundaries, logistics problems and so on. It is pertinent that fragmentation beyond economically viable size needs to be arrested while dismantling feudal structure of landlordtenant system. Purchase of agriculture land is rarely financed by credit institutions in India. Small farmers cannot afford lumpsum payment and thus migration from a small category to higher category is less probable under the existing set up. A credit policy perhaps is an urgent need to arrest fragmentation and enable consolidation. The progress on the consolidation of land holdings in the country has been sluggish. Consequently we have variety of problems depending on the land reforms adopted by different states. But consolidation is an issue in all the states. A study by Besley and Burgess (2000) found a positive impact of consolidation of fragmented land holdings on rural poverty in India. In fact easy and flexible land transactions are a major reform area for positive land use changes. Similarly prevailing tenancy farming in AER 13 should be regulated with proper framework for increased agricultural production. Conning and Robinson (2007) have shown that the tenancy laws designed to help the poor tenants in India, have actually reduced the extent of tenancy. In poorer states prohibition of tenancy by law adversely affected the interests of the rural poor. Thus, it is necessary to recognize tenancy, accord institutional/legal status and provide security of tenure. According to Pender and Kerr (1998) investment in conservation in the country is much lower on leased plots and on plots that are subject to sales restrictions. Prevailing land registry provides only a record of tax payments (Wadhwa 2002) without any authoritative information. Since economic reforms in early nineties, competition for land use has increased immensely. Land disputes and peasant protests have therefore become a daily norm. For rural poor land rental markets serve an important function in equalizing returns to non-tradable factors of production, such as family labor and bullocks in India (Skoufias 1991). Analysis by Banerjee et al. (2002) suggests that the impact of land tenancy reforms in West Bengal state was positive and agricultural productivity increased. Tenants' ability to subsequently acquire limited extent of land through the regular sales markets also increased slightly (Rawal 2001). For India as a whole, tenancy reforms affected poverty reduction, but not productivity growth (Besley and Burgess 2000). It could be summed up that tenancy reforms are vital. It is also imperative to consolidate land holdings as scattering of plots is unfavourable for better productivity. The share of wastelands in the AER is $5 \%$, which can be identified for developing industries ensuring minimum loss of cultivated land. Manufacturing sector often requires large land parcels. Perhaps, less land intensive industry could be encouraged in the AER. In the western part of UP, according to Chaturvedi et al (2011) diversification in agricultural crops is relatively more pronounced in contrast to the other regions. Better market network, roads, agro-processing and irrigation development pre-equipped the western region for diversification. Proximity to national capital Delhi market appeared to be driving diversification in this region. Similar diversification can be encouraged in the disadvantaged districts of AER 13. Moreover, with economic growth of the country, demand for vegetables and fruits has been rising consistently and AER 13 could definitely be beneficiary. 
In AER 11 and 12, forest area is a dominant land use along with cultivation. The current legislation governing forest as a land use in India follows protected area model. Forest and forest land is an exclusive state property. Any interference, even an insignificant activity to be carried by tribal living in the forest needs an approval from a senior forest officer. Forest communities often perceive it to be too rigid primarily due to the long processes, clearances and time spent. Environment protection laws and non government organizations (NGO) further add to the rigid laws. While legitimate objective of protecting forest and environment cannot be doubted, the development also needs to be attended. A perusal of Fig. 2 shows a discernible trend that districts with significant forest cover have poorly developed irrigation resources. There seems to be a relationship as greater forest land implies less irrigation development. However it must also be noted that groundwater utilization in the disadvantaged districts is very low. Thus poor development of irrigation resources cannot be attributed to forest as a protected land use alone.

Table 2. Land use and natural resources in disadvantaged districts of AER11, 12 and 13

\begin{tabular}{|l|c|c|c|}
\hline AER & 11 & 12 & 13 \\
\hline Number of districts & 17 & 25 & 16 \\
\hline Total Geographical Area (ha) & $1,04,91,700$ & $1,74,05,100$ & $47,58,800$ \\
\hline Forest area (\%) & 39.3 & 36.0 & 8.3 \\
\hline Cultivated area (ha) & 33.9 & 41.0 & 74.5 \\
\hline Irrigated area (\%) & 26.1 & 17.1 & 46.2 \\
\hline Wastelands (\%) & 8.2 & 9.4 & 5.1 \\
\hline Degraded land (\%) & 37.7 & 26.1 & 20.9 \\
\hline Per capita cultivated land (ha) & 0.17 & 0.25 & 0.07 \\
\hline Population & $14,27,032$ & $11,55,475$ & $30,17,044$ \\
\hline Population density (persons/sq. km) & 235.1 & 186.1 & 1092.9 \\
\hline Decadal Growth (\%) & 21.2 & 16.0 & 25.0 \\
\hline Rainfall (mm) & 1,260 & 1446 & 1237 \\
\hline Ground water development (\%) & 24.2 & 9.9 & 42.0 \\
\hline Agricultural productivity (Rs/ha) & 20,793 & 26,333 & 32,510 \\
\hline
\end{tabular}

Difference in quantum of forest area among the AERs also supports the hypothesis. In AER 13, forest cover is very low (8\%) as against $74 \%$ cultivated area and $46 \%$ irrigated area. AER 11 and AER 12 on the other hand have $39 \%$ and $36 \%$ of TGA under forest respectively. Consequently less area (AER
$11,33 \%$ and AER $12,41 \%$ ) is cultivated. Surface irrigation resources are developed to the extent of $26 \%$ (AER 11) and $17 \%$ (AER 12) only. Thus there appears to be an empirical converse relationship between forest as a land use and irrigation development (Fig. 2 and 3). 


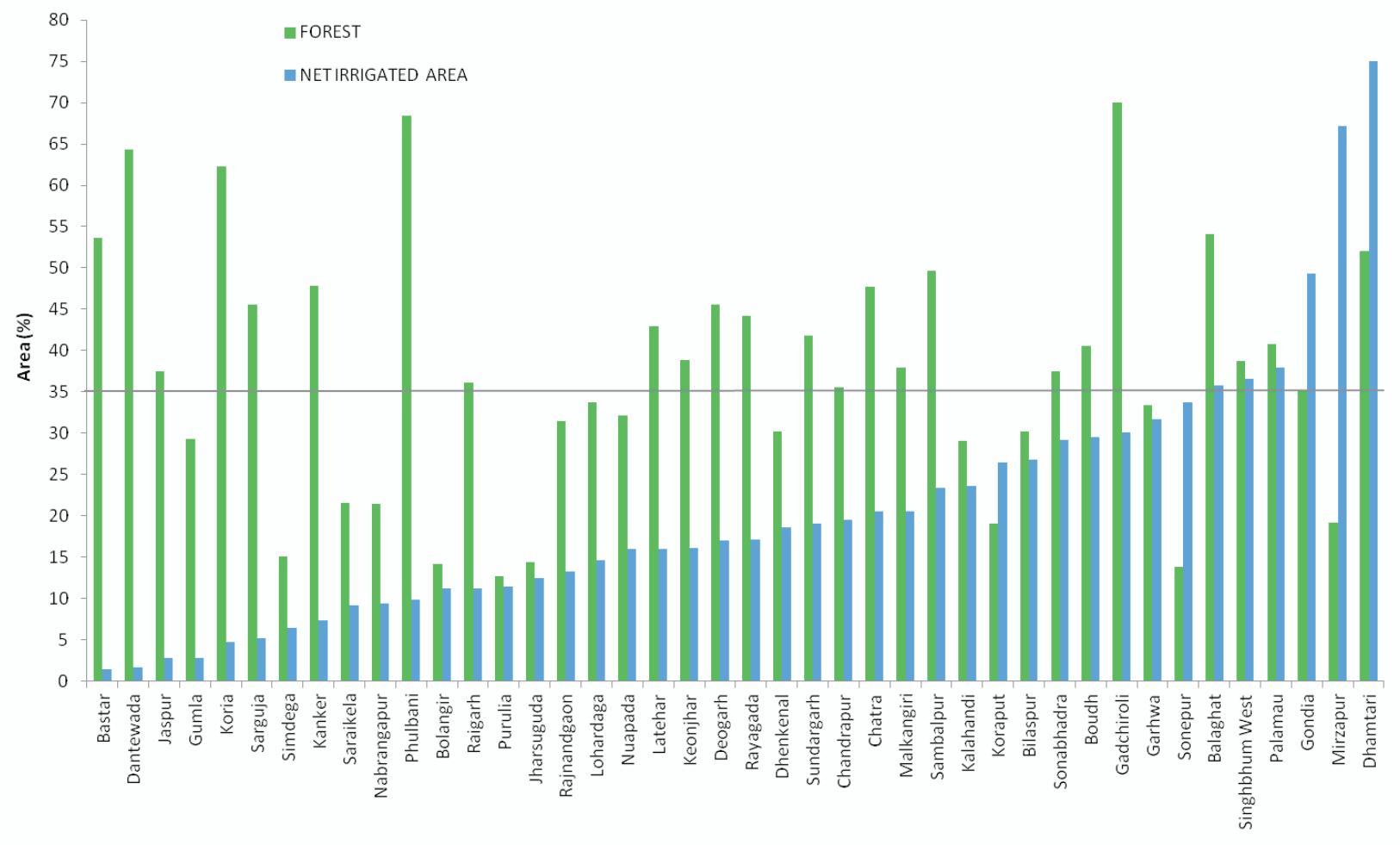

Name of the district

Fig. 2 Inverse relationship between irrigation development and forest cover in disadvantaged districts of AER 11 and 12.

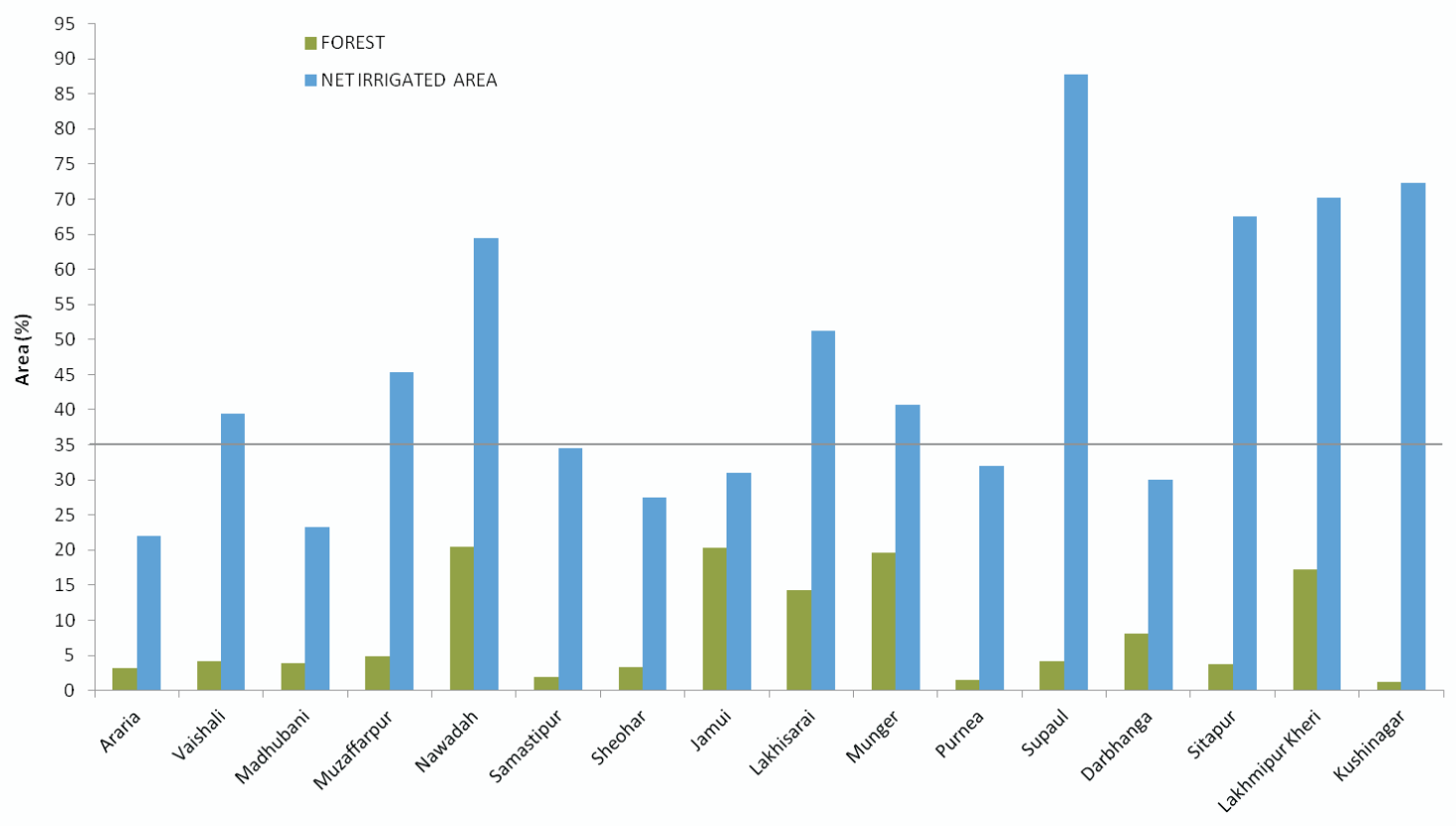

Districts

Fig.3 Irrigation development and forest cover in sixteen disadvantaged districts of AER 13 with little or no forest 


\section{Rice, poverty and water resources development}

Agriculture in AER 11, 12 is characterised by rainfed rice-fallow system. The data indicates that 33 of the 42 districts in AER 11 and 12 are characterized by monocropped rainfed paddy. Groundwater utilization in AER 11 and 12 averages only $18 \%$ in these 33 districts indicating that development of small irrigation technologies like opening of well could alter the scenario significantly. Fig. 4 reveals that these AERs lag far behind in surface and

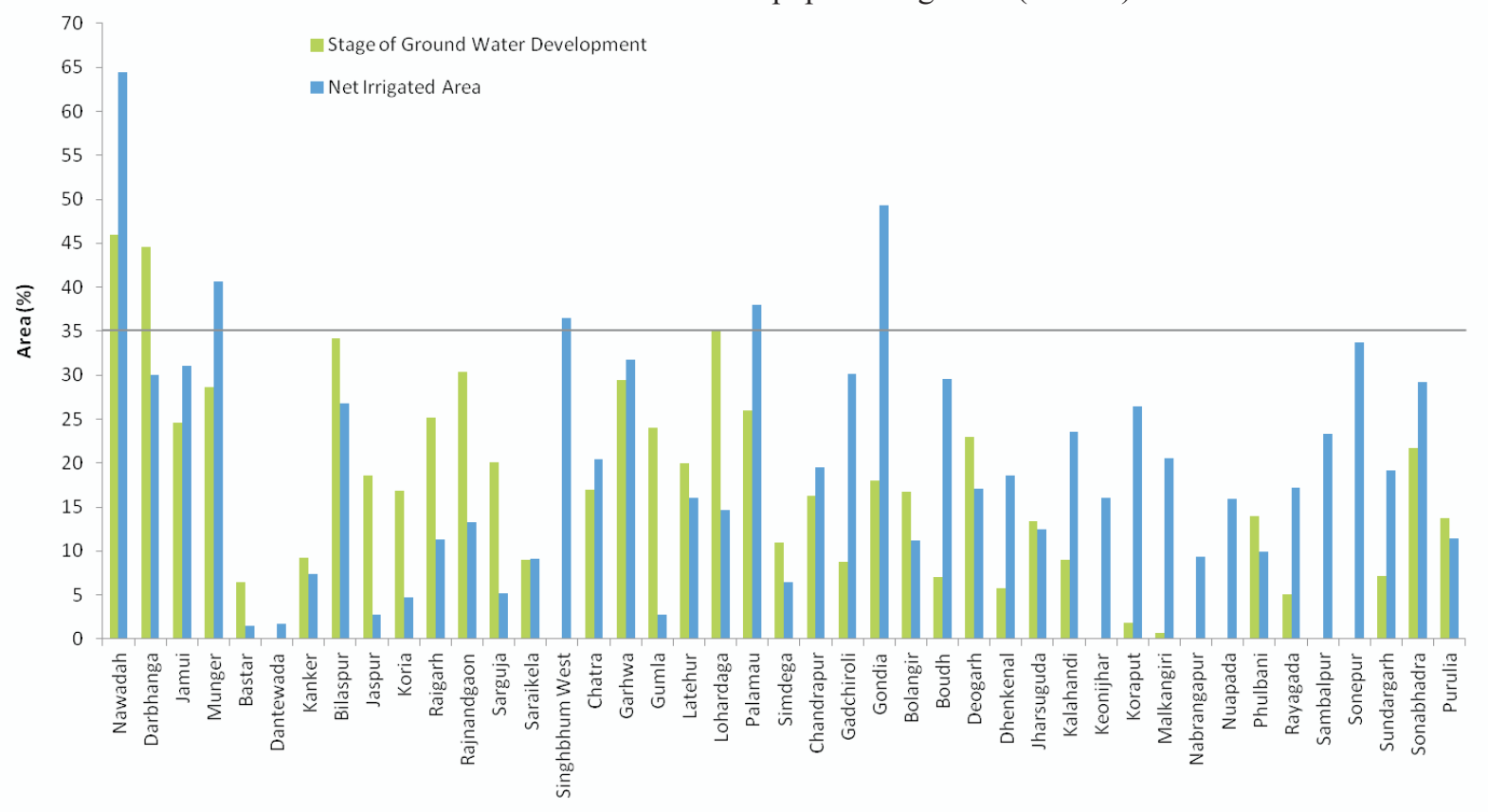

Name of the district groundwater development. Currently most of the human population is totally dependent on monsoon rains for livelihood. Though rice is a pre-dominant crop in AER 13 as well, rice-wheat system is followed in place of rice-fallow due to abundance of water resources in 14 of the 16 districts in AER 13. Agricultural productivity per unit land in AER 13 is more ( Rs. 32510 ha $^{-1}$ ) compared to Rs. 20793 ha $^{-1}$ in AER 11 or Rs. $26333 \mathrm{ha}^{-1}$ in AER 12. These numbers further highlight that despite much better productivity, poverty remains a common threat in AER 13 because of huge population growth (Table 2).

Fig. 4 Poor development of water resources in AER 11 and 12

According to International Rice Research Institute, about $90 \%$ of the world's rice is produced and consumed in Asia, where more than two-thirds of the world's poor live. Our analysis of area under different crops in the disadvantaged/poverty districts reveals rice is a major crop in 121 districts. Thus, there seems to be empirical evidence that rice and poverty exist together. Rainfed rice is generally grown in high rainfall area implying that rainwater is usually available and better management of rainwater could result in higher productivity. Phansalkar and Verma (2004) have emphasised on improved water control as a strategy for enhancing tribal livelihoods mainly through initiating the tribal people in using water, helping them internalise simple water control techniques and skills for growing crops while giving full help in auxiliary inputs and then going in for capital intensive 'hands-off' type components. Samra (2007) has mentioned that rainfed paddy and poverty go hand in hand. Our research results (NAIP experiment) from six experimental villages showed that rice productivity can be improved by 56 to $112 \%$ with technical interventions (Table $3)$ to utilize available water resources. Moreover, without big investment in developing irrigation infrastructure, a concept of community nursery was innovated to overcome inadequacy of water resources during 2009-10 in these villages. 
Table 3. Rice yield in six different villages of Gondia district, Maharashtra after adoption of community nursery practice in $2009-10$

\begin{tabular}{|c|c|c|c|c|c|}
\hline Variety & $\begin{array}{c}\text { Average yield } \\
\text { over last } 20 \\
\text { years }\left(\mathrm{t} \mathrm{ha} \mathbf{~}^{-1}\right)\end{array}$ & $\begin{array}{l}\text { Variety } \\
\text { advised }\end{array}$ & $\begin{array}{c}\text { No. of } \\
\text { farmers } \\
\text { supervised }\end{array}$ & $\begin{array}{l}\text { Yield during } \\
2009-10\left(\mathrm{t} \mathrm{ha}^{-1}\right)\end{array}$ & $\begin{array}{c}\text { Advantage } \\
\text { accrued (\%) }\end{array}$ \\
\hline \multirow{3}{*}{$\begin{array}{l}\text { Local, varieties } \\
\text { marketed by } \\
\text { private enterprises }\end{array}$} & \multirow[t]{3}{*}{1.62} & Khamang & 87 & 3.44 & 112 \\
\hline & & $\begin{array}{l}\text { Sindewahi- } \\
1010\end{array}$ & 7 & 2.91 & 79 \\
\hline & & HMT & 56 & 2.53 & 56 \\
\hline
\end{tabular}

Usually farmers prepared their paddy nursery in late June after the onset of monsoon in Gondia (AER 12) district of Maharashtra state in (India) where these villages are located. Thus nursery plants are routinely transplanted in the month of July to August. The rainiest period of July and August month is thus usually lost as the plants are too young to utilize available rainwater. Recession of monsoon in the month of September coincides with crop reproductive phase and thus farmers often suffer setback. An early preparation of nursery is not possible due to non-availability of water. In a community action, the lone source of water in each village, a privately owned tubewell was utilized for raising a common nursery. The tubewell owner provided land as well as water to the villagers. The results were highly encouraging evidenced by increased yields. Early transplanting facilitated early harvest and in-turn facilitated winter crop using residual soil moisture, hitherto unthinkable proposition. The farmers in AER 11, 12, 13 thus may be encouraged to advance the date of paddy transplanting for better utilization of rainwater. The concept of community nursery may not be easily replicable but it definitely demonstrates the potential of small water control technologies. It could be inferred that water driven cropping pattern changes can assist the native population to sustain livelihood without changes in existing land use i.e. without bringing more area under cultivation.

Policy of encouraging farmers to open wells could be an option. However, our experience in the study villages shows that farmers exhibit reluctance to invest in opening wells because of poverty and space lost to the well. Unlike rest of India, where more than 60 or $70 \%$ of total geographical area under agricultural use is a norm, the disadvantaged district population has to depend on substantially less cultivated area (40 to $50 \%$ area under cultivation). The reluctance can also be attributed to fragmentation of land as irrigating a small parcel of land through investment in well is perceived to be less rewarding. Irrigation development in AER 13 could enable three crops a year along with existing rice-wheat system. The soils are also fertile enriched by silt depositions brought in by rivers and their tributaries.

Table 4. Area and productivity of major crops in AER11, 12 and 13

\begin{tabular}{|l|c|c|c|c|c|c|}
\hline \multirow{4}{*}{ Crop } & \multicolumn{6}{|c|}{ AER No. } \\
\cline { 2 - 7 } & \multicolumn{2}{|c|}{ AER 11 } & \multicolumn{2}{c|}{ AER 12 } & \multicolumn{2}{c|}{ AER 13 } \\
\cline { 2 - 7 } & $\begin{array}{c}\text { Area } \\
\text { (ha) }\end{array}$ & $\begin{array}{c}\text { Average } \\
\text { Productivity } \\
\mathbf{( t ~ h a ~}^{-1} \text { ) }\end{array}$ & $\begin{array}{c}\text { Area } \\
\text { (ha) }\end{array}$ & $\begin{array}{c}\text { Average } \\
\text { Productivity } \\
\left(\mathbf{t ~ h a}^{-1}\right)\end{array}$ & Area (ha) & $\begin{array}{c}\text { Average } \\
\text { Productivity } \\
\left.\text { (t ha }^{-1}\right)\end{array}$ \\
\hline Rice & 139070 & 0.95 & 143058 & 1.23 & 91942 & 1.3 \\
\hline Lathyrus & 49015 & 0.53 & - & - & - & - \\
\hline Small millets & 23093 & 0.30 & 33814 & 0.19 & - & - \\
\hline Cotton & - & - & 25891 & 1.41 & - & - \\
\hline Wheat & - & - & - & - & 61079 & 1.8 \\
\hline Maize & - & - & - & - & 20333 & 2.06 \\
\hline
\end{tabular}


The rice productivity gap between less developed (in terms of irrigation ) AER 12 and well developed AER 13 is surprisingly narrow (Table 4). It could be argued that there exists a huge untapped potential in AER 11 to attain higher rice productivity. According to Chapagain (2009), water foot print of rice in India is next only to Pakistan in the world. Thus water use efficiency in India needs a huge positive correction. Water management can be distinguished in two different categories, rainwater management wherein uncertainties of monsoon inherently restrict measures to overcome water shortages and irrigation water management wherein better control is possible. Thus water exercises different kind of control over land use in AER11 and 12 as compared to AER 13. The current choice of crops in AER 11,12 and 13 is an ample reflection of natural resources available to the native population.

Population density in AER 13 is very high (1092 persons $\mathrm{km}^{2}$ ) as against 235 and 181 persons $\mathrm{km}^{2}$ in AER 11 and 12 respectively. Therefore the per capita land availability is AER 11 and 12 is significantly higher (despite less area under cultivations) as against AER 13. But land resources in AER 11 and 12 are low in terms of soil fertility. AER 13 has very fertile alluvial soils occurring in the plains. AER 11 and 12 have shallow, acidic, low fertile soils on undulating terrain. Bringing more area under cultivation (to achieve higher agricultural production) or horizontal expansion is likely to result in loss of forest area and related damages in addition to low productivity of cleared land. Poor soils of AER 11 and 12 must receive better management. . In AER 13 use of agriculture inputs and their optimal utilization holds the key. Also, laws governing forest as a land use cannot be same in all the AERs.

Poverty in AER 13 can be attributed to excessive population putting severe strain on available natural resources as evidenced by high magnitude of cultivated area and irrigation development. AER 11 and 12 on the other hand appear to be victims of rigid forest protected laws as far as water resources development is concerned.

Another perspective could be the use of (Non Timber Forest Produce, NTFP) in livelihood of communities in AER 11 and 12. A survey of six representative NAIP villages ( $>600$ households) indicated that NTFP is a primary source of livelihood in forest and forest fringed villages (Table 5). However, it was noted that there is a substantial depletion of NTFP resources and the villagers are going dangerously deeper into the forest to collect NTFP. In fact, about 100 million people in India are classified as forestdependent (Poffenberger 2002).These studies highlight the dilemma faced by governments. Arguments for stringent protection of forest land are strengthened by each incidence of wild animal attack on trespassing human. An experiment in representative village indicated that activities such as pisciculture could be promoted to utilize common property resources such as water tank to earn livelihood. Simultaneously plantation could be taken up in buffer zone/ transition zone to promote NTFP. Thus village common resources like water tanks, pasture lands, as well as part of protected forest lands need to be utilized by making amendments in existing land use. If need be, legislations should be modified to permit and regulate buffer zones in forest lands. The changes are likely to conserve forest lands better than the existing protection. Development plans and land use strategies in AER 11 and AER 12 must be aimed at irrigation development and formulating sustainable NTFP utilization. Forest lands near villages need to be used for short, middle and long term plan to provide NTFP as a means of livelihood. Thus each village should have a land use plan for forest-based livelihood with emphasis on conservation of existing forest cover.

The per capita land availability in AER 13 has declined to such an extent that the current land use cannot be expected to sustain livelihood of enormous population. Other uses such as industrial development, commercial plantation etc. could provide better returns/sustain the population. Another factor is tenancy and/or share cropping. An informal arrangement between landlord and the farmers is prevailing in AER 13 for a long period. The arrangement is often detrimental to the development as landlords are often unwilling to invest in infrastructure development. The tenants or share farmers usually have limited financial resources and may depend completely on landlord for all the inputs except for labour. It is obvious that the land use decisions are mostly ad-hoc without any consideration of long term goals. According to Mukherji (2013) the state of West Bengal has already taken at least four policy decisions in this direction i) a change in groundwater law which will make it easier for small and marginal farmers to invest in wells and tubewells ii) reduction change in one time electricity connection charges for agricultural tubewells for the same purpose iii) one time capital cost subsidy for pump electrification to the tune of Rs. 8000 per farmer and iv) capital cost subsidy up to Rs. 20,000 per pump set for those 
wanting to invest in pumps. These steps have boosted agricultural productivity in the state. Similar changes are occurring in the Bihar state and it is logical for other states to follow suit. Thus changes are occurring in AER 13 but across the board changes are not yet evident and need to be implemented in earnest. It has been suggested that such policy changes are also necessary in Bihar (AER 13). Though water is the prime factor controlling land use, in AER 13, we consider excessive population as the most critical factor. On the other hand in AER 11 and 12, we argue in favour of small irrigation technologies.

Table 5. Income from different sources of livelihood in selected cluster of Gondia district, Maharashtra

\begin{tabular}{|c|l|c|}
\hline $\begin{array}{c}\text { Sr. } \\
\text { No. }\end{array}$ & \multicolumn{1}{|c|}{ Parameter } & Year \\
\hline \multirow{2}{*}{1.} & Centrality of agriculture & $2008-9$ \\
\cline { 2 - 3 } & Per cent share of agriculture -based income & 13.3 \\
\cline { 2 - 3 } & Percent share of forest -based income & 40.1 \\
\cline { 2 - 3 } & Per cent share of income from other sources & 46.6 \\
\hline \multirow{2}{*}{2.} & Facets about agriculture & \\
\cline { 2 - 3 } & Average size of land holding (acres) & 4100 \\
\cline { 2 - 3 } & Net returns from agriculture (Rs. acre $\left.{ }^{-1}\right)$ & 85 \\
\cline { 2 - 3 } & Per cent rainfed area & 6765 \\
\hline \multirow{2}{*}{3.} & Facets about Capital Investment & 66.48 \\
\cline { 2 - 3 } & Average capital investment(In Rs. acre $\left.{ }^{-1}\right)$ & \\
\cline { 2 - 3 } & Per cent going to agriculture & \\
\hline
\end{tabular}

It could be summarized that land use planning in relation to the available natural resources and potential indicated by the 'agro-ecological region' approach is a better way of examining the sustainability of livelihood of population residing in identified disadvantaged districts of the eastern India. Therefore, it is essential to make inventory of each AER for its natural resources base, investigate the potential of the resources to support native population and formulate policies which would be effective and more likely to succeed in improving livelihood.

\section{References}

Banerjee, A.V., Gertler, P. J., Ghatak M (2002). Empowerment and Efficiency: Tenancy Reform in West Bengal. The Journal of Political Economy, $110,239-280$

Besley, T. and Burgess, R. (2000). Land reform, poverty reduction and growth: evidence from India. The
Development Economics Discussion Paper No. 13. The Suntory Centre, Suntory and Toyota International Centres for Economics and Related Disciplines, London School of Economics, London.

Chand, Ramesh, Garg, Sanjeev and Pandey, Lalmani (2009). Regional Variations in Agricultural Productivity A District Level Study. Discussion Paper NPP 01/200. National Centre for Agricultural Economics and Policy Research. (ICAR). New Delhi 110012

Chandran, P.; Tiwary, P.; Bhattacharyya, T.; Mandal, C.; Prasad, J.; Ray, S. K.; Sarkar, D.; Pal, D. K.; Mandal, D. K.; Sidhu, G. S.; Nair, K. M.; Sahoo, A. K.; Das, T. H.; Singh, R. S.; Srivastava, R.; Sen, T. K.; Chatterji, S.; Patil, N. G.; Obireddy, G. P.; Mahapatra, S. K. (2014). Development of soil and terrain digital database for major food-growing regions of India for resource planning. Current Science 107, 1420-1430. 
Chapagain, Ashok (2009). Water Footprint of rice quantifying the rainbow of virtual water fluxes related to rice trade. Re-thinking Paradigms: Water and Food Security. 4th Marcelino Botin Foundation water workshop Santander, Spain.

Chaturvedi, Arun, Hajare, Trilok, Patil, Nitin and Sarkar, Dipak (2011) Enhancing Tribal Livelihood - A Resource Management Approach. Technical Bulletin, Division of Land Use Planning, NBSS\&LUP, Nagpur.

Conning J. H. and Robinson J. A. (2007). Property rights and the political organization of agriculture. Journal of Development Economics 82, 416-447.

Gajbhiye K.S. and Mandal C. (2008). Agro-ecological zones, their soil resource and cropping systems at http://www.agricoop.nic.in/Farm\%20Mech\%20P DF/05024-01.pdf

http://cgwb.gov.in

Manjunatha, A.V., Reza, Anik Asif, Speelman, S. and Nuppenau, E.A. (2013). Impact of land fragmentation, farm size, land owner ship and crop diversity on profit and efficiency of irrigated farms in India. Land Use Policy 31, 397-405.

Mukherji Aditi (2013). Strategies for Managing India's Groundwater. Last accessed on June 2013 at http://wle.cgiar.org/blogs/2013/02/12/strategiesfor-managing-indias-groundwater
Pender, J. (1998). Population growth, agricultural intensification, induced innovation and natural resource sustainability: an application of neoclassical growth theory. Agricultural Economics. 19, 99-112.

Pender, J. and Kerr, J. (1998). Determinants of farmers' indigenous soil and water conservation investments in semi-arid India. Agricultural Economics 19: 113125.

Phansalkar and Verma (2004). Improved water control as strategy for enhancing tribal livelihoods Economic and Political Weekly XXXIX, 3469 - 3476.

Poffenberger, M. (2006). People in the forest: community forestry experiences from Southeast Asia Int. J. Environment and Sustainable Development. 5, 57-69

Rawal, V. (2001). Agrarian reforms and land markets: A study of land transactions in two villages of West Bengal 1977-95. Economic Development and Cultural Change 49, 623

Samra, J.S. (2007). National Rainfed Authority of India as communicated in personal interview. Text available a $\mathrm{t}$ h t $\mathrm{t} \mathrm{p}: / / \mathrm{w}$ w w . b u s i n e s s standard.com/india/news/surinder-sudlosingproposition/295971/

Skoufias, E. (1991). Land tenancy and rural factor market imperfections revisited, Journal of Economic Development, 16, 37-55.

Wadhwa, D.C. (2002). guaranteeing title to land. Economic and Political Weekly, XLVIII ; 4699-4722.

Received: February, 2016

Accepted : April, 2016 